\title{
Application of College Task Collection for Informatics and Information System Students
}

\author{
Latius Hermawan ${ }^{1 *}$, Maria Bellaniar Ismiati ${ }^{2}$ \\ ${ }^{1,2}$ Musi Charitas Catholic University, Bangau No. 60 Street, Palembang 30113, Indonesia \\ 1tiuz.hermawan@ukmc.ac.id; ${ }^{2}$ bella@ukmc.ac.id; \\ Corresponding Author*
}

\begin{tabular}{l}
\hline A R T I C L E I N F O \\
\hline Article History: \\
Received January 8, 2020 \\
Reviced January 21, 2020 \\
Accepted January 24, 2020 \\
Available Online February 28, 2020 \\
Keywords: \\
Application, \\
Task, \\
Web.
\end{tabular}

Kata Kunci:

Aplikasi,

Tugas,

Web.

\section{Correspondence:}

Telephon: +6285928883832

E-mail

tiuz.hermawan@ukmc.ac.id

\begin{abstract}
The web is very popular with internet users because it makes it easy for internet users to search and search for information. Web information system for educational institutions is used as a means to provide, in addition, it is used as conducting lecture activities, storing lecture process data, and so on. The information that is accessed is very diverse, one of which is for students and lecturers supporting courses is to open an academic portal, collect lecture assignments and create assignments in the form of Information Systems. Existing task collection Web portal, still rarely used by lecturers and students as a media to collect assignments there are already several features in the existing portal including storing student and lecturer data that teaches, setting the task collection limit, entering the assignment name, etc. Unfortunately, the display is not yet user-friendly (the display cannot adjust to the device that accesses it automatically) so that if opened on a smartphone, the menu display and writing become smaller, causing menu selection to be more difficult. The results of this study are the construction of a lecture assignment application for students of Informatics and Information Systems that are user-friendly. By using this application, students can view assignments and collect assignments online while lecturers can provide and download assignments online and in real-time.
\end{abstract}

\begin{tabular}{l} 
ABSTRAK \\
\hline Web cepat sekali populer di lingkungan pengguna internet, karena memberikan \\
kemudahan pada pengguna internet untuk melakukan penelusuran dan pencarian \\
informasi. Web sistem informasi untuk lembaga pendidikan digunakan sebagai sarana \\
untuk memberikan, selain itu digunakan sebagai melakukan kegiatan-kegiatan \\
perkuliahan, penyimpanan data proses perkuliahan dan sebagainya. Informasi yang \\
diakses sangat beragam, salah satunya bagi para mahasiswa dan dosen pengampu mata \\
kuliah adalah membuka portal akademik, pengumpulan tugas kuliahnya dan \\
pembuatan tugas yang berbentuk Sistem Informasi. Portal Web pengumpulan tugas \\
yang sudah ada, masih jarang digunakan oleh para dosen dan mahasiswa sebagai \\
media mengumpulkan tugas, sebenarnya sudah ada beberapa fitur pada portal yang \\
sudah ada diantaranya penyimpanan data-data mahasiswa dan dosen yang mengajar, \\
pengaturan batas pengumpulan tugas, memasukan nama tugas, dll. Sayangnya \\
tampilan yang ada belum user friendly (tampilan belum bisa menyesuaikan dengan \\
perangkat yang mengakses secara otomatis) sehingga jika dibuka di smartphone, \\
tampilan menu dan tulisannya menjadi lebih kecil, sehingga menyebabkan pemilihan \\
menu menjadi lebih sulit. Hasil penelitian ini adalah telah dibangunnya aplikasi \\
pengumpulan tugas kuliah bagi mahasiswa Informatika dan Sistem Informasi yang \\
user friendly. Dengan menggunakan aplikasi ini, mahasiswa mampu melihat tugas dan \\
mengumpulkan tugas secara online sedangkan dosen mampu memberikan dan men- \\
download tugas secara online dan real time.
\end{tabular}

\section{Introduction}

The web is very popular with internet users because it makes it easy for internet users to search and search for information. The internet is becoming a very popular tool today because the internet provides a variety of infinite information. Web information system for educational institutions is used as a means 
to provide, in addition, it is used as conducting lecture activities, storing lecture process data and so on [1][3].

In Indonesia, netizens spend a lot of time on the mobile web. Around $82 \%$ of netizens in Indonesia access the mobile web, while $9 \%$ each accesses via the desktop. One smartphone can be used to undergo many activities. From the composition of netizens themselves, more than $70 \%$ of netizens only use smartphones to access [2]. The information that is accessed is very diverse, one of which is for students and lecturers supporting courses is to open an academic portal, collect lecture assignments and create assignments in the form of Information Systems.

Existing task collection Web portal, still rarely used by lecturers and students as a media to collect assignments there are already several features in the existing portal including storing student and lecturer data that teaches, setting the task collection limit, entering the assignment name, etc. Unfortunately, the display is not yet user-friendly (the display cannot adjust to the device that accesses it automatically) so that if opened on a smartphone, the menu display and writing become smaller, causing menu selection to be more difficult.

Appearance on an existing portal makes students feel lazy to open an existing web portal because they are still using old web components such as text boxes, buttons, combo boxes. Furthermore, some lecturers experienced where assignments could still be collected even though the pre-determined time had passed. So we need an application that can handle these problems with features that have been made before.

The construction of this online assignment portal is expected to facilitate lecturers and students in gathering lectures so that in any form of devices students can easily collect their assignments and students do not feel fed up with the small menu writing on their smartphone screens. Lecturers can easily create new assignments using existing devices easily.

\section{Literature Review}

\subsection{Information Systems}

An information system is a system within an organization that meets the needs of daily transaction processing that supports the organization's operational functions which is managerial with the strategic activities of an organization to be able to provide certain outside parties with the necessary reports [3].

\subsection{Website}

Understanding the website is an internet facility that connects documents in a local or longdistance scope. Documents on the website are called web pages and links on the website allow users to move from one page to another (hypertext), both between pages stored on the same server and servers around the world [3].

\subsection{User Friendly}

Easily accessible or opened on mobile devices (Smartphones and Tablets) and looks can be adjusted (adaptive) and respond (responsive) according to the screen size of the mobile device [4].

\subsection{PHP and MySQL}

PHP (Hypertext Preprocessor) is a main server-side script language that is inserted into HTML that is run on the server and can also be used to create desktop applications. According to Betha Sidik, in his book entitled Web Programming with PHP [5], states that:

"PHP is generally known as a programming language scripts that make HTML documents on the fly that are executed on a web server, HTML documents generated from an application, not an HTML document created using a text editor or HTML editor, also known as a server-side programming language "

\subsection{Related Research}

In Anwar's research [6] in serving the implementation of the teaching and learning system, the academic service system is needed and is a very vital thing for the implementation of the teaching and 
learning process in continuity and quality. Without an academic information system, the teaching and learning process will not be a teaching and learning process. With the existence of web technology and the existence of these constraints it is an idea to create a software application that is able to manage the filling of KRS properly, so that these constraints can be handled with this software. With this software it is expected to provide other alternatives to the current KRS charging system. The results obtained from the Online Academic Application are very helpful for all parties, both from the University itself and from students. Seen from the University, the staff work lighter, can immediately see students who fill out their Study Plan Cards Online, can see the percentage of interested in a course and others, so that decisions can be made immediately whether or not the course will be held.

Furthermore, research conducted by [4] where the management of academic activities is still done manually, in the sense of not using an integrated information system, such as in the process of new student registration, preparation of lecture schedules, filling student KRS, managing college attendance, and managing student grades. Because it is still done manually, the Academic Field encounters various obstacles in these processes, especially those related to resources and time needed, along with the increasing number of students being managed. So the authors propose a research proposal based on Desktop Wira Medika Bali STIKES Academic Information System Design. By doing this academic information system design, it is expected that all academic activities or processes contained in Wira Medika Bali STIKES can be translated into programming languages or computerized properly to be implemented, so as to overcome various obstacles encountered. Academic Information System at Wiramedia STIKES was successfully developed by designing using UML diagrams, as well as coding programs with C \# language and Ms. database. SQL Server. This developed system aims to assist academic processes at STIKES Wiramedika.

The same thing was done by [7] where a management system of student lecture assignments can be used as an alternative to improve effectiveness and overcome problems that sometimes arise, in the education and teaching process carried out by lecturers, especially in managing student assignments. During this time the lecturer gives assignments to students and collected in the form of hardcopy, or also softcopy with email media. If you use hardcopy or print out documents, there will be a lot of work assignments in the lecturer's office and the assignment cannot be useful especially for students who are collecting assignments and generally for students or other people around campus. Likewise with the collection of assignments via email too many obstacles, the first lecturer is not enough time to examine all of these tasks, internet disruptions that may occur, not to mention if there are students who collect the same tasks with other students. From the experience of gathering college student assignments above came the idea to create a website that can be used to accommodate student assignments. On the web students can log in and send assignments in the form of text, documents, images and videos and can also see their own assignments. The results of this research are information system of Student Lecture Services online work can help in managing student lecture assignments to lecturers, monitoring and reviewing the assignments. The system that has been implemented on Internet hosting can be accessed anytime and anywhere by lecturers as administrators and students as users, so students can send their assignments at any time and are not constrained by time and space.

\section{Research and System Development Method}

\subsection{Research Method}

Sampling was conducted at the Informatics and Information Systems Study Program, Faculty of Science and Technology, Musi Charitas Catholic University. The sample used was 30 students of Informatics and Information Systems. The sampling technique used was purposive sampling, which is often used in quantitative studies. Purposive sampling is intentional sampling in accordance with the required sample requirements. Another name for purposive sampling is judgmental sampling, which is sampling based on the assessment of researchers regarding anyone who is suitable / meets the requirements to be sampled.

Samples that meet the requirements in accordance with the objectives of this study are Informatics and Information Systems students who have used this system and have been supported by Mr. Latius Hermawan and Ms. Maria Bellaniar. After observing the students in the Informatics and Information Systems study program and in accordance with the requirements above, 30 students of 
Informatics and Information Systems were obtained. By using purposive sampling, the sample criteria obtained are in accordance with the research conducted.

The data used in this study are primary data. Data obtained by collecting questionnaires from 30 students of Informatics and Information Systems in accordance with the above conditions. Questionnaires were distributed on campus during working hours and after the end of the lecture so as not to interfere with lectures.

\subsection{System Development Method}

The Rapid Application Development phase consists of 3 phases, namely [8]:

\subsubsection{Requirements Planning}

At this stage, users and analysts conduct a kind of meeting to identify the purpose of the application or system and identify the information needs to achieve the goal. At this stage the most important thing is the involvement of both parties, not just the approval of the proposal that has been made.

\subsubsection{User Design}

At this stage is to carry out the design process and make improvements if there are still design mismatches between the user and the analyst. For this stage, the activeness of the users involved is crucial to achieving the goal, because the user can directly comment if there is a mismatch in the design. Typically, users and analysts gather together and sit at a circular table where each person can see one another without obstacles. After the design of the system to be created has been approved both by the user and analyst, then at this stage the programmer develops the design into a program. After the program is completed either partly or as a whole, the testing process is carried out on the program whether there are errors or not before it is applied to an organization. At this time the user can provide feedback on the system that has been made and the agreement about the system. The most important thing is that user involvement is needed so that the system developed can provide satisfaction to the user and in addition, the old system does not need to be run in parallel with the new system.

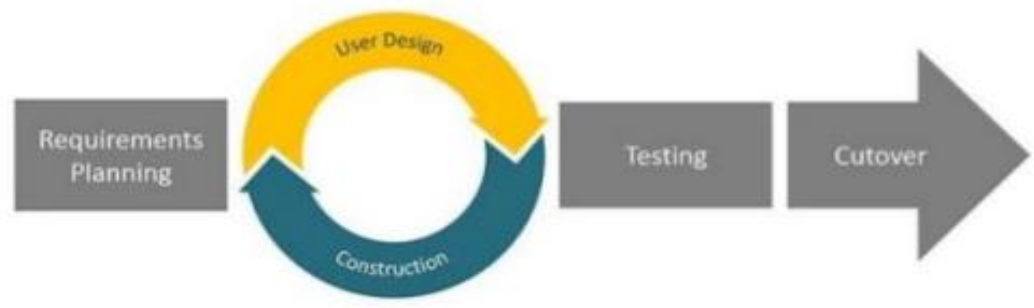

\subsubsection{Construction}

Figure 3.1. Rapid Application Development

The construction step aims to build a system based on the results of the modeling design that has been obtained. Based on the results of the modeling design, construction is in the form of coding or codification of the program. Codification is the process of writing source code or source code that will build the system in terms of system interfaces and logic or the process of the system itself. The source codes used in this codification stage include HTML source code as an interface design or system interface, as well as PHP source code as a programming language that forms the logic or process of a system.

\subsubsection{Testing}

The last step taken was the evaluation phase. The evaluation phase is carried out by testing the results of system design that has been built at the method implementation stage. The testing phase that is done is testing the system based on use case diagrams, testing the types of data in the system by doing the data input process use data. 


\section{Results and Discussion}

The picture below shows the user login page which is divided into 2 namely lecturers and students. If a student correctly enters a username and password, they will enter the main page as well as the lecturer.

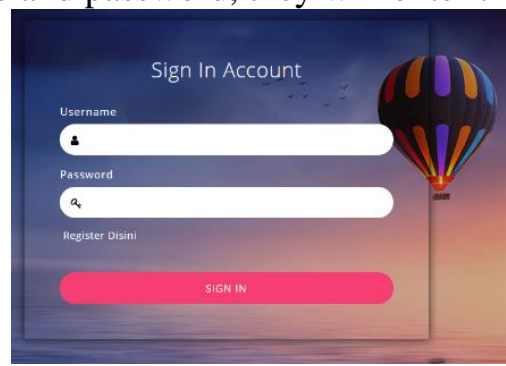

Figure 5.1. Display Task Portal Login

Figure 5.2 above shows the page when the lecturer will make a new assignment to students. Lecturers input the name of the assignment, the deadline for assignment and the name of the course. Then click the plus button so that the assignment description can be displayed when students have logged in using the username and password to view the assignments given by the lecturer.

PORTAL TUGAS

Silahkan Masukan Tugas Baru
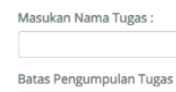

Batas Pengumpul.
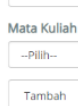

Figure 5.2. Display page input of new assignments from the lecturer

The picture below is the download page of the work done by the lecturer when he is going to check the work done by the students. In the drop down menu, the lecturer can choose the course whose assignment will be examined and then

click the submit button.

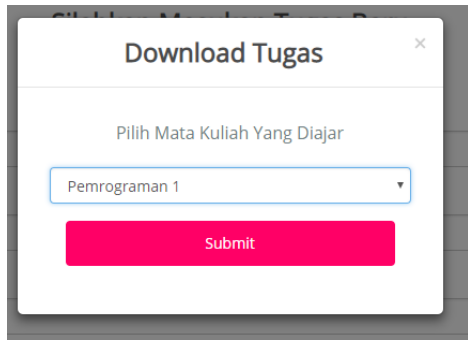

Figure 5.3. Task Download Page Display (Lecturer)

If the lecturer will examine the student's assignment, the lecturer must click the download button next to the names of the students who have sent their assignments. 


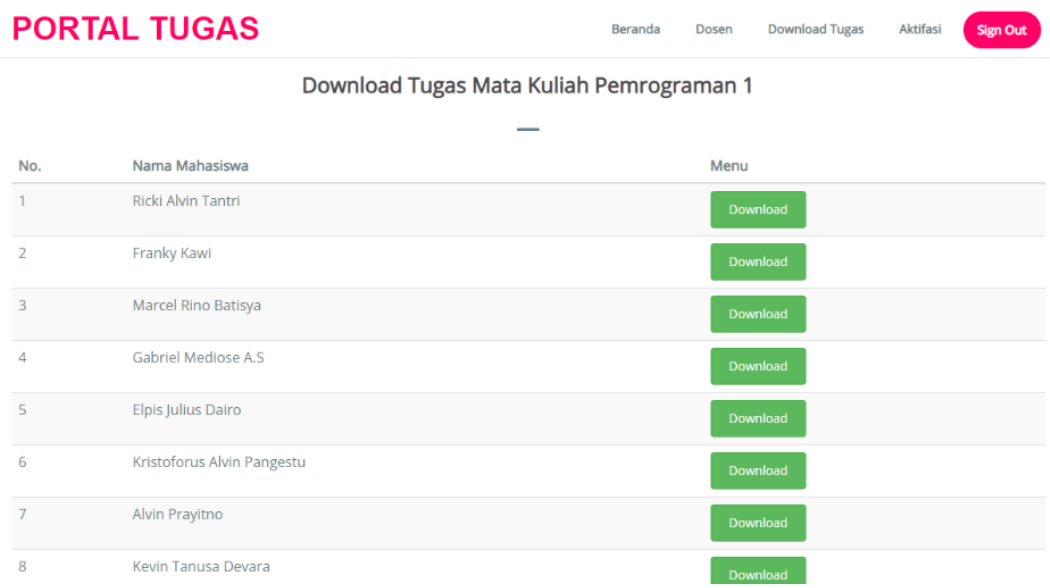

Figure 5.4. Display Task List Pages that have been collected

The picture below shows the task list page and the deadline for assignment collection. The green color at the deadline for assignments indicates that students can still collect assignments through the assignment portal. While the red color at the deadline for assignment indicates that students can not collect assignments through the task portal

Daftar Tugas Mata Kuliah
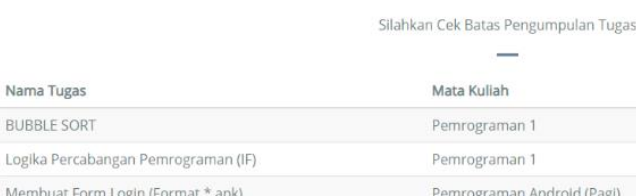

-

Logika Percabangan Pemrograman (I)

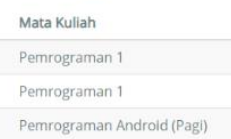

Batas Akhir

2019-01-02-07.12 WiB

2018-11-19-07.12 WIB

2018-10-23-07.12 WiB

Figure 5.5. Display task list and deadline for assignment collection

Figure 5.6 below shows the main page if successfully logged in as a student. Students can see what assignments have been given or added by lecturers who are in charge of the subject matter and students can also see the deadline for the collection of assignments.

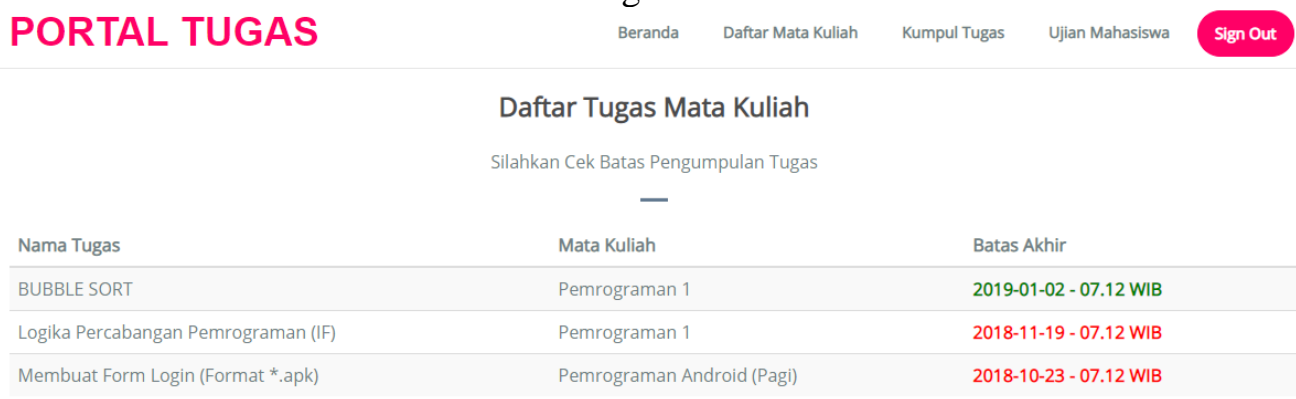

\section{Figure 5.6 Display Main page of students}

Figure 5.7 above shows the assignment upload page for students. To upload assignments, students must choose the name of the course that their assignment will be collected and then click the submit button. 


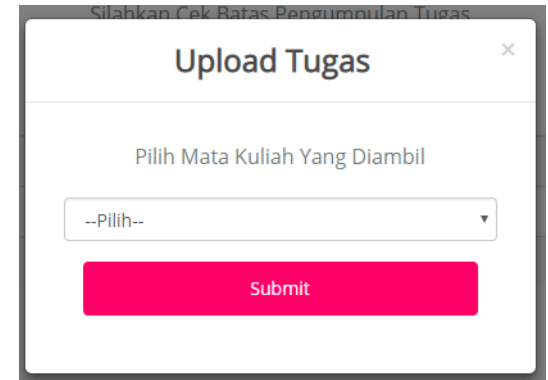

Figure 5.7 Display Page Upload Assignments by students

Figure 5.10 shows an upload page for student assignments that contains details on how to collect assignments and their deadlines. If the student wants to send his assignment, then the student must click on the select file first then click the upload button. If a student collects assignments past the date, then the upload button will not be clickable, just as when a student has uploaded his assignment. The upload button can be clicked when the assignment period is not too late and the student has never submitted an assignment. After students successfully send assignments, there will be a status of "Congratulations, Franky Kawi has uploaded the assignment" and likewise when students have not uploaded the assignment.

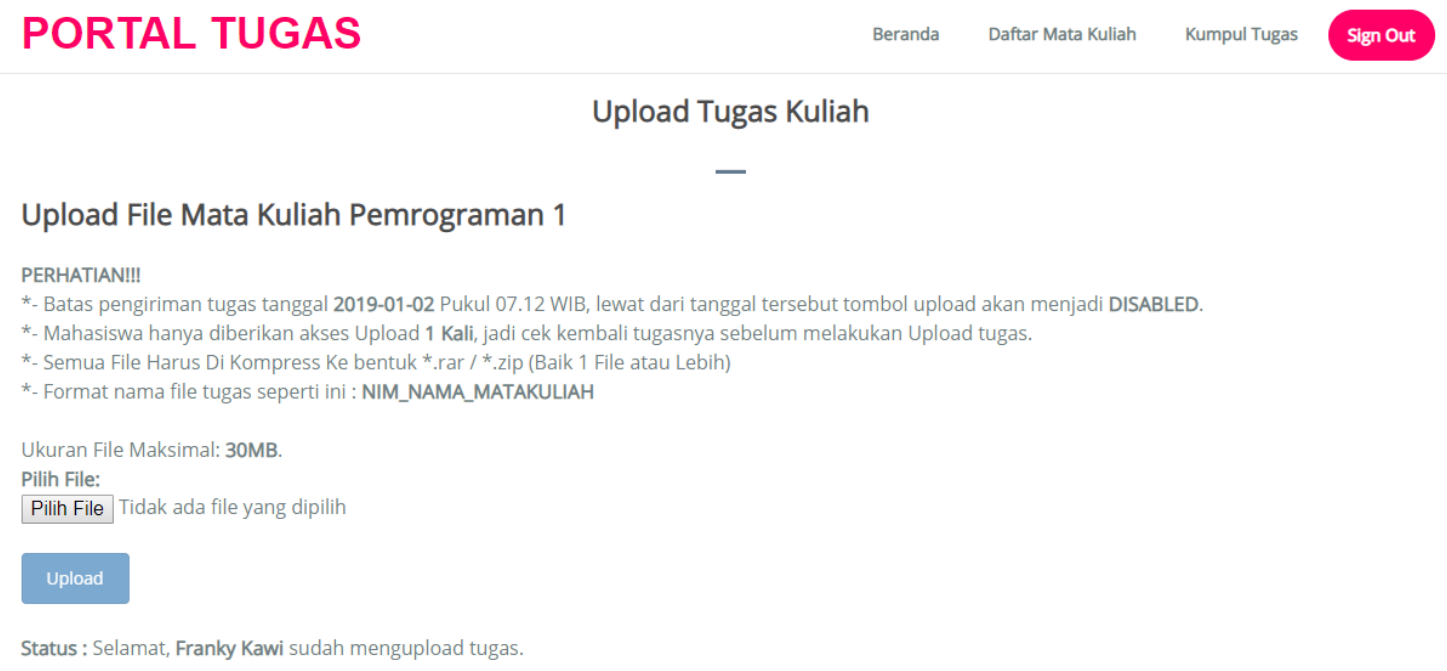

Figure 5.7 Display Upload Page for Student Lecture Assignments

\section{Conclusion}

By the task portal application that has been made, the results obtained are that this application can function as it should and in the process, this application can support the teaching and learning process well. The application that has been made is also more user friendly and its appearance can be adapted to various devices rather than the existing task portal (based on the results of the questionnaire). Based on the results of student questionnaires, as many as $\pm 90 \%$ feel helped by the application of this task portal and $\pm 93 \%$ feel it looks more user friendly than the existing portal.

\section{References}

[1] Ani, M. Steven R. 2016. "Pengembangan Portal Tugas Akhir Program Studi Teknik Informatika Universitas Sam Ratulangi." Jurnal Teknik Informatika, Volume 7, No. 1.(2016), ISSN : 2301-8364

[2] News. 2017. "Penggunaan Smartphone di Indonesia Tahun 2017". http://dewinajournal.foutap.com/penggunaan-smartphone-di-indonesia-tahun-2017/, acceessed on 15 Mei 2018, 19.35 .

[3] Fatta, Al Hanif. 2007. “Analisis \& Perancangan Sistem Informasi”, Yogyakarta : Penerbit ANDI. 
[4] Adnyana BMI. 2016. "Perancangan Sistem Informasi Akademik STIKES Wira Medika Bali Berbasis Desktop”. Jurnal Sistem Dan Informatika Vol. 10, No. 2.

[5] Betha Sidik. 2012. "Pemrograman Web dengan PHP”. Informatika,. Bandung.

[6] Anwar C,. 2015. “Sistem Informasi Akademik Online Sebagai Penunjang Sistem Perkuliahan ”. Faculty of Information Technology, Budi Luhur University.

[7] Danuri M, 2014. "Rancang Bangun Sistem Pengelolaan Tugas Kuliah Mahasiswa Secara Online". INFOKAM Nomor II / Th. IX/ September / 14.

[8] Pressman, Roger S. 2010. “Software Engineering: A Practitioner's Approach. (7th. Edition)”. New York: McGraw-Hill Higher Education. 